\title{
Morphotaxonomy, culture studies and phytogeographical distribution of Amphiroa fragilissima (Linnaeus) Lamouroux (Corallinales, Rhodophyta) from Myanmar
}

\begin{abstract}
Articulated coralline algae belonging to the genus Amphiroa collected from the coastal zones of Myanmar were identified as A. fragilissima based on the characters such as shape of intergenicula, branching type, type of genicula (number of tiers formed at the genicula), shape (composition and arrangement of short and long tiers of medullary cells), presence or absence of secondary pit-connections and lateral fusions at medullary filaments of the intergenicula and position of conceptacles. A comparison on the taxonomic characters of $A$. fragilissima growing in Myanmar and in different countries was discussed. A. fragilissima showed Amphiroa-type which was characterized by transversely divided cells in the first division of the early stages of spore germination in laboratory culture. Moreover, the distribution ranges of $A$. fragilissima along both the coastal zones of Myanmar and the world oceans were presented. In addition, ecological records of this species were briefly reported.
\end{abstract}

Keywords: A. fragilissima, articulated coralline algae, corallinaceae, corallinales, germination patterns, laboratory culture, morphotaxonomy, Myanmar, phytogeographical distribution, Rhodophyta
Volume 7 Issue 3 - 2018

\author{
Mya Kyawt Wai \\ Department of Marine Science, Mawlamyine University, \\ Myanmar
}

\section{Correspondence: Mya Kyawt Wai, Lecturer, Department of Marine Science, Mawlamyine University, Myanmar,} Emailmrakyawtwai@gmail.com

Received: May 31, 2018 | Published: June 12, 2018

\section{Introduction}

The coralline algae are assigned to the family Corallinaceae of the order Corallinales. There are two types of coralline algae, the articulated (geniculate) corallines and the nonarticulated (nongeniculate) corallines. The family Corallinaceae was composed of four subfamilies namely, Metagoniolithoideae, Corallinoideae, Lithophylloideae (Amphiroideae sensu Johansen) ${ }^{1}$ and Mastophoroideae. ${ }^{1,2,3}$ The genus Amphiroa is one of the seven genera of subfamily Lithophylloideae, and belongs to the tribe Amphiroeae. ${ }^{3}$ This genus comprises 49 species currently accepted and widespread in tropical and subtropical regions. ${ }^{4}$ The genus Amphiroa is characterized by dichotomous or verticillate branching and intergenicula well separated by conspicuous genicula. ${ }^{1}$ In Amphiroa, the reproductive cells are produced within conceptacles which are always borne on the surfaces of the intergenicula. Conceptacles of dioecious sexual plants are more crowded than those of tetrasporangial plants. Each conceptacle opened by a single pore, through which the reproductive cells exit. ${ }^{5}$

In Myanmar, Martens ${ }^{6}$ recorded A. tribulus Lamouroux and $A$. fragilissima Lamouroux, from Pegu, Diamond I. and South Andaman Is. Kyi $\mathrm{Win}^{7}$ listed $A$. dilitata Lamouroux (=A. anceps (Lamarck) Decaisne) A. ephedraea (Lamarck) Decaisne and Amphiroa sp. Moreover, Kyaw Soe and Kyi $\mathrm{Win}^{8}$ reported $A$. dilitata Lamouroux ( $=$ A. anceps (Lamarck) Decaisne), A. ephedraea (Lamarck) Decaisne and Amphiroa sp. Soe-Htun ${ }^{9}$ also reported the occurrence of $A$. fragilissima (Linnaeus) Lamouroux in Rakhine and Tanintharyi coastal zones. Soe-Htun et al,. ${ }^{10}$ reported $A$. foliacea Lamouroux, A. fragilissima (Linnaeus) Lamouroux and from the Gwa coastal areas, Rakhine State. Soe-Htun et al., ${ }^{11}$ accounted the 3 species of Amphiroa, viz., A. fragilissima (Linnaeus) Lamouroux, A. foliacea
Lamouroux and $A$. anceps (Lamarck) Decaisne, along the 3 coastal zones of Myanmar. Mya Kyawt Wai ${ }^{12}$ also described five species of Amphiroa from Myanmar namely, A. foliacea, A. anceps, A. gracilis, A. fragilissima and $A$. beauvoisii.

In the present study, the characters such as shape of intergenicula, branching type, type of genicula (number of tiers formed at the genicula), shape (composition and arrangement of short and long tiers of medullary cells), presence or absence of secondary pit-connections and lateral fusions at medullary filaments of the intergenicula and position of conceptacles had been used in identification of genera and species of articulated coralline algae. Regarding the reproductive structures, the reproductive cells of Amphiroa are produced within conceptacles which are borne on the lateral position of the intergenicula. The location of conceptacle primodia has been useful in delimiting the genera of articulated coralline algae. The reproductive cells exit by a single pore in each conceptacle. ${ }^{5}$ So far, species of the articulated coralline algae collected from the coastal zones of Myanmar have been identified as A. fragilissima (Linnaeus) Lamouroux based on the morphological and anatomical characters.

To study the germination patterns of $A$. fragilissima have been cultured under the laboratory conditions. The cultured material, $A$. fragilissima grows on the rocks of the tide pools in the intertidal to subtidal zones of Tanintharyi coastal zones: from Lampi I. to Mway Taung, deltaic coastal zones: Setse and Rakhine coastal zones: from Leik I. to Gyeik Taw. For the culture study, A. fragilissima were collected from the Chaungtha coastal areas. It grows abundantly in the tide pools and shallow bays in the intertidal regions of Chaungtha coastal areas. The early stages of cell divisions, development of tetraspores and germination patterns of this species under culture were presented in this study. 
The objectives of this study are: 1) to revise the taxonomy of the species of Amphiroa based on the morphology of vegetative and reproductive structures; 2) to understand the sporelings development of A. fragilissima; 3) to understand the germination pattern of articulated coralline alga Amphiroa, and 4) to know the distribution ranges of this species along the 3 coastal zones of Myanmar and the world oceans.

\section{Materials and methods}

All of the specimens of articulated coralline algae were collected from the coastal zones of Myanmar. Most of the collections were preserved in 5\% formaldehyde-seawater and some were prepared for herbarium specimens. These specimens were deposited in the Herbarium of Department of Marine Science, Mawlamyine University (MMB), Mawlamyine. For anatomical studies, individual pieces of the branches were fixed and decalcified in Susa fixative $(\mathrm{HgCl}, 4.5 \mathrm{~g}$; trichloroacetic acid, $2.0 \mathrm{~g}$; glacial acetic acid, $4.0 \mathrm{ml}$; formalin, $20.0 \mathrm{ml}$; water, $76.0 \mathrm{ml}$; Johansen ${ }^{13}$ ) for $24 \mathrm{~h}$ and sectioned by razor blade and stained in Ehrlich's hematoxylin. Vegetative and reproductive structures were studied under the dissecting and compound microscopes and photographed with a Sony DSC- WX7 digital camera, processing with Adobe Photoshop CS2. Sizes of these structures were measured under the compound microscope using an ocular meter. The taxonomic aspect of this study followed the classification system of Johansen, ${ }^{1}$ Silva \& Johansen, ${ }^{2}$ Womersely \& Johansen, ${ }^{14,15}$ Aguirre et al., ${ }^{3}$ Bittner et al. ${ }^{16}$ \& Guiry \& Guiry. ${ }^{4}$ The local distributional range of this taxon was arranged from the reference collection of specimens examined in the Department of Marine Science, Mawlamyine University and worldwide distribution range of this alga was also recorded from the literature. Moreover, habitats and associated algae of each species were recorded for the ecological data during the period of field collections. Moreover, live specimens were cultured at the laboratory to observe the developmental stages of vegetative and reproductive structures.

For the cultural studies on the genus Amphiroa, fertile tetrasporic plants of $A$. fragilissima, were collected from the coastal zones of Chaungtha (Lat. $16^{\circ} 57^{\prime} \mathrm{N}$, Long. $94^{\circ} 26^{\prime}$ E), Pathein Township, in 2012. The materials were kept in ice-box and brought to the laboratory immediately after collections. The cultured apparatus such as Petri dishes, glass slides, cover slips, and forceps were washed with tap water and then they were sterilized with boiling water. Salinity of sterile seawater was adjusted to 32 and 35 with the aid of a refractometer. And then, PES culture medium ${ }^{17}$ was prepared for spore culture. The branches were examined for the presence of mature spores before the materials were used in the experiments. In order to do this, selected branches with conceptacles were first decalcified in dilute hydrochloric acid. The exised fertile branches were washed in sterile seawater using small writing brushes. After being carefully washed, the plants were dried with tissue paper and were kept under the dark condition for overnight. In the next morning, the plants were placed on cover slips which were placed in each Petri dish $(60 \mathrm{mmx} 13 \mathrm{~mm})$ containing $30 \mathrm{ml}$ of prepared culture medium. These Petri dishes were placed under the natural light condition at room temperature for spores liberation and settlement. These branches were left undisturbed for $8 \mathrm{~h}$ and during this period spores were shed naturally from conceptacles. The liberated tetraspores attached to the cover slips and the branches were removed from Petri dishes.

Tetraspores that settled on the cover slips were transferred to each Petri dish containing $30 \mathrm{ml}$ of prepared culture medium. The numbers of cell divisions were recorded and sizes of spores and germlings were measured under the compound microscope using ocular meter and this was done at $2 \mathrm{~d}$ interval. The developmental stages of tetraspore germlings were photographed by digital camera, processing with Adobe Photoshop CS2. The medium was changed at $3 \mathrm{~d}$ interval. Germanium dioxide $\left(\mathrm{GeO}_{2}\right)$ was added to the medium to suppress growth of diatoms. Light intensity was measured by the Light Meter Type 214.

\section{Results}

\section{Classification of the species Amphiroa fragilissima (Linnaeus) Lamouroux}

Phylum: Rhodophyta

Class: Rhodophyceae

Order: Corallinales

Family: Corallinaceae

Subfamily: Lithophylloideae

Genus: Amphiroa Lamouroux

Species: A. fragilissima (Linnaeus) Lamouroux

Amphiroa fragilissima (Figures 1-11)

Type locality: Jamaica: as cited in Silva et al. ${ }^{18}$

Type: Linn: as cited in Silva et al. ${ }^{18}$

\section{Description}

Thalli pulvinate-caespitose or forming a dense clump, pale pink in colour, $2.5-4.0 \mathrm{~cm}$ high, consisting of erect, cylindrical branches, attached by disc-like holdfast; branch apices mostly blunt; branching regular repeatedly dichotomous, sometimes trichotomous; branching commonly occur in the genicula, rarely in the intergenicula; angles variable but mostly narrowed; cortical cells ovate to hexagonal, $5-9 \mu \mathrm{m}$ broad in surface view; genicula swollen and prominent, formed at the forks, with occasional nodal adventitious branches, frequently elsewhere as well, $140-400 \mu \mathrm{m}$ in height and $200-450 \mu \mathrm{m}$ in diameter, consisting of cortical layers with 3-5 tiers of medullary cells with secondary pit-connections; intergenicula, terete or subterete, $0.5-5.5 \mathrm{~mm}$ long and up to $0.2-0.3 \mathrm{~mm}$ in diameter, composed of 7-8 tires of long medullary cells, $40-90 \mu \mathrm{m}$ high and $7-15 \mu \mathrm{m}$ in diameter, alternating with 1 tier of short cells, $10-30 \mu \mathrm{m}$ high and $8-20 \mu \mathrm{m}$ in diameter, consisting 2-6 layers of cortical cells; medullary filaments of the intergenicula with primary and secondary pit-connections; the lines formed by the secondary pit-connections at the one-third below tops of medullary cells; conceptacles laterally at the intergenicula; uniporate tetrasporangial conceptacles, $50-80 \mu \mathrm{m}$ high and 190$340 \mu \mathrm{m}$ in diameter at inside; tetrasporangia about $30-70 \mu \mathrm{m}$ long, $20 \mu \mathrm{m}$ in diameter.

Specimens examined. Taninthayi coastal zone: Lampi I. (Tint Swe, 4.i.2008; MMB 10253-10255); High I. (Yin Yin Htay, 12.xi.2008; MMB 10256); Wa Maw (Yin Yin Htay, 18.iv.2007; MMB 1025010252); Nyaw Byin (Soe-Htun, 11.i.2002; MMB 10247-10249); Kampani (Mya Kyawt Wai, 29.ix.2011; MMB 13086-13088; Aung Aung Htaik 7.3.2012; MMB 13089-13091); Mway Taung (Soe-Htun, 5.iv.2001; MMB 10244). Deltaic coastal zone: Setse (4 $4^{\text {th }}$ Yr. Students, 1980; MMB 06855; Group 3, 24.viii.1983; MMB 06857; Chaw Chaw Su, 4.iv.2000; MMB 06881; Aung Myo Tun, 4.iii.2006; MMB 07082; 
Mya Kyawt Wai, 25.vii.2009; MMB 10184-10193; 22.viii.2009; MMB 13077-13078; 15.xii.2009; MMB 13083-13084; 4.vii.2010; MMB 13068; 26.x.2010; MMB 13080; 8.xi.2010; MMB 13071; 13.vi.2010; MMB 13074; 15.ix.2010; MMB 13075). Rakhine coastal zone: Leik I. (Daw Nyo Nyo Tun, 3.12.2011; MMB 13065); Mawtin Point (Aye Aye Thet, 6.iv.2001; MMB 10464; Mya Kyawt Wai, 17.xi.2009; MMB 10229); Hi Gyi (Daw Thida Myint, 10.iii.2012; MMB 13062); Kyar Kan (Mya Kyawt Wai, 17.xi.2009; MMB 10235); Zee Gyaing (Mu Mu Aye and Myint Myint Than, 17.ii.1980; MMB 00613); Pashyu Gyaing (Nay Myo Aye, 5.iv.2001; MMB 04380; Mya Kyawt Wai, 16.xi.2009; MMB 10232); Sinma (Aung Myo San, 20.ii.2012; MMB 13059); Ngwe Saung (Mya Kyawt Wai, 14.xi.2009; MMB 10238; 24.ii.2012; MMB 13056; 1.iv.2018; MMB 111591); Phoe Kalar I. (Soe-Htun, 1.iv.1996; MMB 10262; Thandar Hlaing, 1.iv.1996; MMB 03355; Mya Kyawt Wai, 5.iv.2013; MMB 13147; 2.iv.2018; MMB 111590); Makyee (Mu Mu Aye, 4.x.2006; MMB 10257); Wetthey Gyaing (Mya Kyawt Wai, 30.ix.2012; MMB 13053-13055); Maw Shwe Gyaing (Soe-Htun, 7.x.2002; MMB 10241-10243); Sin Phyu Gyaing (Soe-Htun, 8.iv.2004; MMB 10259); Maungshwelay (Aung Myint, 14.iv.1980; MMB 00784; Yan Lin Aung, 6.iv.2004; MMB 06859; Maung Maung San, 6.iv.2004; MMB 06860; Sai Noom Seng, 6.iv.2004; MMB 06861; Phyo Zayar Naing, 6.iv.2004; MMB 06862; Myo Min Tun, 2.v.2013; MMB 1314013142); Leik Tet Gyaing (Saw Ohmar Khin, 6.iv.2004; MMB 06858); Gyeik Taw (Myo Min Tun, 30.iv.2013; MMB 13143-13145; Soe Pa
Pa Kyaw, 30.iv.2013; MMB 13150-13151).

\section{Distribution}

(i) Myanmar distribution. Tanintharyi coastal zone- Lampi I., High I., Wa Maw, Nyaw Byin, Kampani, Mway Taung; deltaic coastal zone: Setse; Rakhine coastal zone: Leik I., Mawtin Point, Hi Gyi, Kyar Kan, Zee Gyaing, Pashyu Gyaing, Sinma, Ngwe Saung, Phoe Kalar I., Makyee, Wetthey Gyaing, Maw Shwe Gyaing, Sin Phyu Gyaing, Maungshwelay, Leik Tet Gyaing, Gyeik Taw (Table 1) (Figure 26).

(ii) Phytogeographical distribution. Atlantic Ocean- Brazil, Trinidad \& Tobago, Lesser Antilles, Venezuela, Panama, Costa Rica, Belize, Cuba, Florida, North Carolina, Jamaica, Bahamas, Puerto Rico, Netherlands Antilles, Barbados, Isla Guadalupe, Virgin Islands, Bermuda, Azores, France, Italy, Sardinia, Algeria, Morocco, Madeira, Canary Islands, Mauritania, Senegal, Gambia, Ascension; Indian Ocean- Réunion, Mauritius, Rodrigues Island, Chagos Archipelago, Seychelles, Madagascar, Comoros, Mozambique, Tanzania, Kenya, Somalia, Egypt, Saudi Arabia, Qatar, Iran, Pakistan, India, Laccadive Islands, Maldives, Sri Lanka, Bangladesh, Myanmar, Andaman Islands, Nicobar Islands; Indo-Pacific Region- Indonesia, Singapore, Thailand, Vietnam, Philippines; Pacific Ocean- Taiwan, China, Japan, Federated States of Micronesia, Papua New Guinea, Solomon Islands, Western Australia, Queensland, Fiji, Hawaiian Islands, Easter Island, Colombia, Chile ${ }^{19}$ (Figure 27).

Table I The distributional range of A. fragilissima along the coastal zones of Myanmar

\begin{tabular}{|c|c|c|c|c|c|c|c|}
\hline \multirow{2}{*}{$\begin{array}{l}\text { Sr. } \\
\text { No. }\end{array}$} & \multirow{2}{*}{ Species } & \multicolumn{2}{|c|}{ TCZ } & \multicolumn{2}{|c|}{ DCZ } & \multicolumn{2}{|c|}{ RCZ } \\
\hline & & From & To & From & To & From & To \\
\hline I. & A. fragilissima & $\begin{array}{l}\text { Lampi I. } \\
\text { Lat. } 10^{\circ} \\
58^{\prime} \mathrm{N}, \\
\text { Long. } \\
98^{\circ} 08^{\prime} \mathrm{E}\end{array}$ & $\begin{array}{l}\text { Mway Taung } \\
\text { Lat. I } 4^{\circ} \\
27^{\prime} \mathrm{N}, \\
\text { Long. } \\
98^{\circ} 00^{\prime} \mathrm{E}\end{array}$ & $\begin{array}{l}\text { Setse } \\
\text { Lat. } 15^{\circ} \\
52^{\prime} \mathrm{N}, \\
\text { Long. } \\
97^{\circ} 35^{\prime} \mathrm{E}\end{array}$ & - & $\begin{array}{l}\text { Leik I. } \\
\text { Lat. I5 } \\
5 I^{\prime} \mathrm{N} \text {, Long. } \\
94^{\circ} 17^{\prime} \mathrm{E}\end{array}$ & $\begin{array}{l}\text { Gyeik Taw } \\
\text { Lat. I } 8^{\circ} \\
21^{\prime} \mathrm{N} \text {, Long. } \\
94^{\circ} 20^{\prime} \mathrm{E}\end{array}$ \\
\hline
\end{tabular}

Abbreviations:TCZ, The Taninthayi coastal zone; DCZ, The deltaic coastal zone; RCZ, The Rakhine coastal zone.

Ecological notes. A. fragilissima occur as a dense clump at the tide pools of intertidal and subtidal zones all year round. These plants mostly associate with the genera Caulerpa, Halimeda and Padina, and can also found in the seagrass beds. Reproductive structures are observed from September to March.

\section{Culture studies on development of tetraspores of Amphiroa fragilissima (Linnaeus) Lamouroux}

After extrusion from the conceptacles, tetraspores adhered together at the pore of conceptacle about 1-2h (Figure 12). After that, they released from the conceptacles. The liberated tetraspore were reddish brown in colour and spherical to subspherical and contain numerous red plastids. The spores adhered lightly to the cover slips by a layer of secreted mucilage during a few hours after their liberation from the conceptacles. The newly attached tetraspores were $40-80 \mu \mathrm{m}$ in diameter (Figure 13). This material become hardened and revealed a halo around each spore. The attached spores were flattened and against the substratum with an increase of diameter. Within a few hours of attachment, tetraspores began a first division. The first division gave rise to the spores consisting two approximately equal cells formed by a transverse cell wall during 1-2h after attachment (Figure 14). A second division was formed by another longitudinal cell wall which was at right angle to the first-formed septum took place during 5-6h. This division divided the two-celled tetraspore into four nearly equal cells (Figure 15). After 9h, the curved third divisons which were at right angle to the second division occurred and these divisions were parallel with first division forming the 8 unequel cells (Figure 16). Consequently, the fourth divisions formed at the four centered cells and these divisions were parallel with each other and at right angle to the first division forming 12-celled stages during 12h (Figure 17). The fifth divisions formed in the outer part of the third divisions. This division resulted in the formation of a 16-celled stage, $60-90 \mu \mathrm{m}$ in diameter during 15-16h (Figure 18). The fifth and fourth divisions took place mostly at the same time. Successive divisions formed in the peripheral cells to give a 24-celled stage as seen in surface view during 19-20h (Figure 19). These developed sporelings were in contact with the substratum and calcification was detected at these stages by decalcification with hydrochloric acid. The marginal cells of the sporelings grew to initial cells of the basal crust.

After 1-2d, the sporelings became hemispherical forms which were $60-100 \mu \mathrm{m}$ in diameter and $10-20 \mu \mathrm{m}$ in height (Figure 20) (Figure 21). The initial of upright axis was observed on the 3rd day 
in culture. In this stage, the first uncalcified geniculum formed as colorless cells at the center of hemispherical sporelings and it was $20-30 \mu \mathrm{m}$ in height (Figure 22). Continuously, the first intergeniculum also formed as darker cells at the end of the first geniculum. The first calcified intergeniculum was up to $50 \mu \mathrm{m}$ long and $50 \mu \mathrm{m}$ broad on the 4th day. The basal crust grew at the periphery and firmly attached the substratum. So, a recognisible plant with a distinct upright axis and a fully developed basal crust occurred in laboratory culture during the 7th day (Figure 23) ( Figure 24). On the 7th day, the intergeniculum reached to $100 \mu \mathrm{m}$ in height and $50 \mu \mathrm{m}$ in diameter.

The young genicula were composed of one to two tiers of long and uncalcified cells while the young intergenicula consisted of short and long medullary filaments with peripheral cortex.

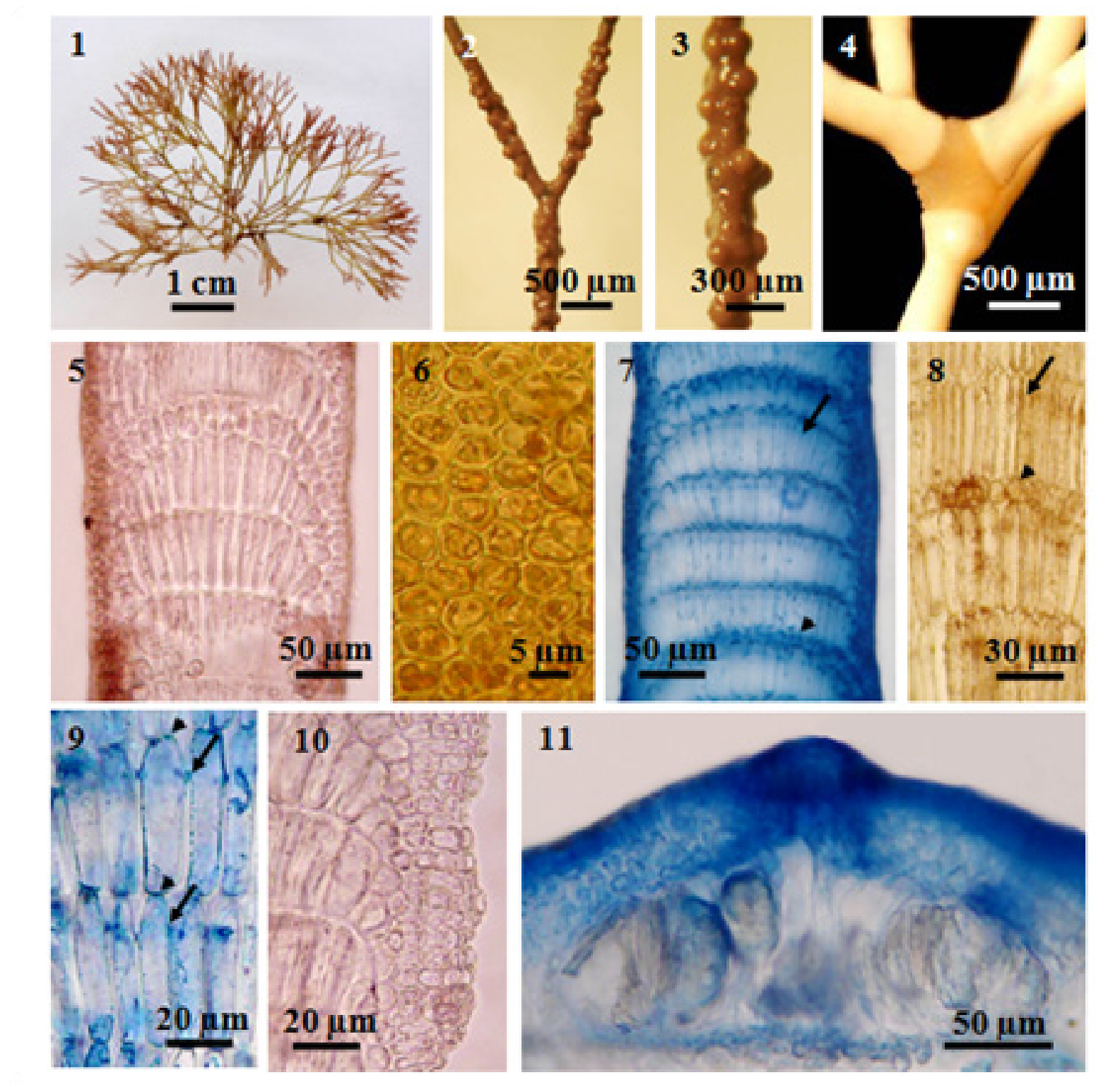

Figures I-I I The external and internal structures of Amphiroa fragilissima: (I) Habit; Figures. (2-3) Intergenicula with conceptacles; (4) Branches with swelling at the node; (5) Longitudinal section of multi-tiered geniculum; (6) Surface view, showing cortical cells; (7-8) Longitudinal section of intergenicula: (7) Alternation of short (arrowhead) and long (arrow) medullary cells; (8) Tiers of short (arrowhead) cells among long (arrow) cells; (9) Primary (arrowheads) and secondary (arrows) pit-connections; (I0) Cortex and medullary cells; (I I) Tetrasporangial conceptacle.

In the spore germination of $A$. fragilissima, the erect shoots initiated at the centre of small hemispherical sporelings while the fringe-like and fan-shaped growth were produced by the divisions of the marginal cells. These fan-shaped thalli were calcified in the inner portions and continuously grew in the outer cells. The width of extensive crusts reached $100-150 \mu \mathrm{m}$ in diameter after 11d (Figure 25). 

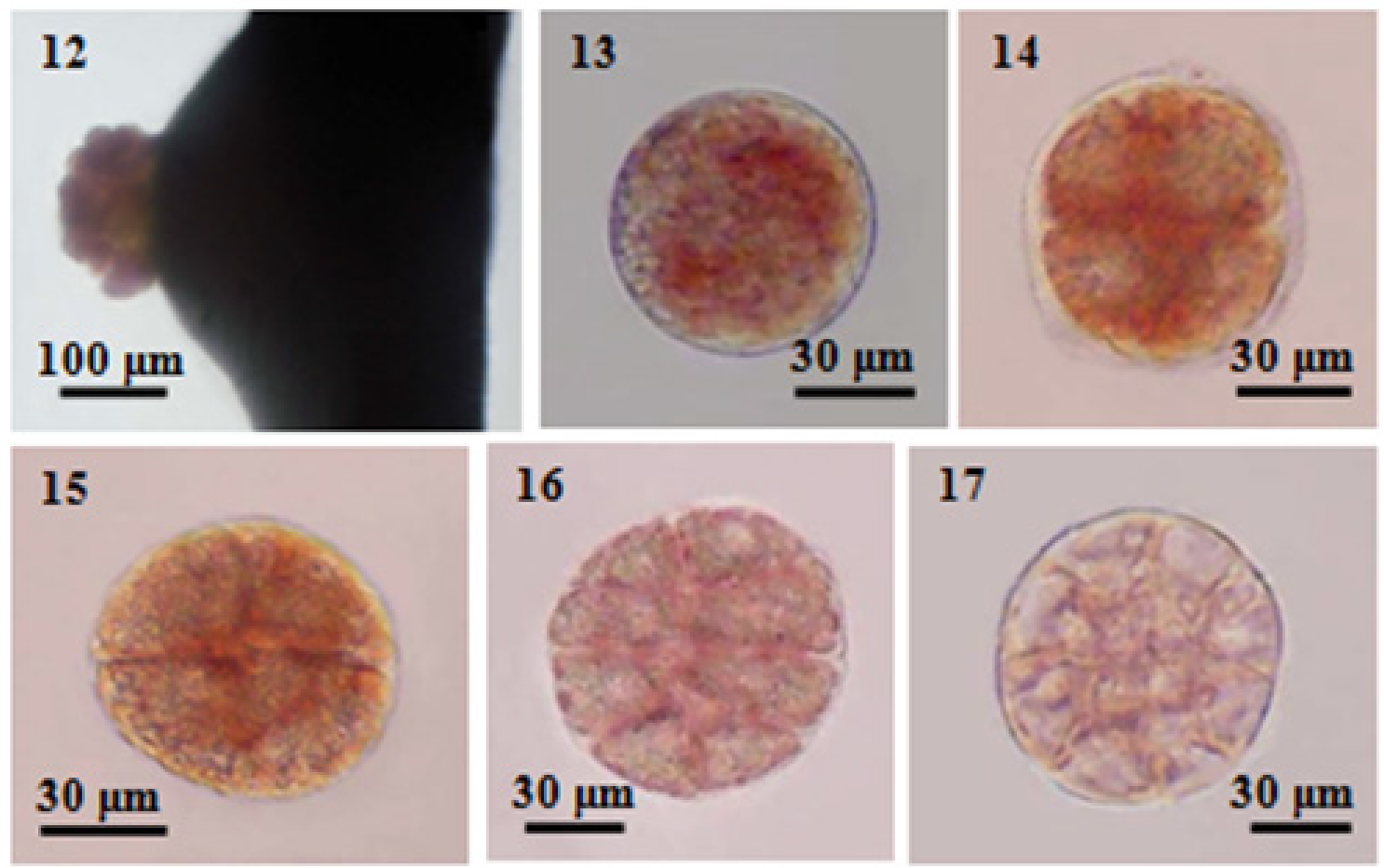

17
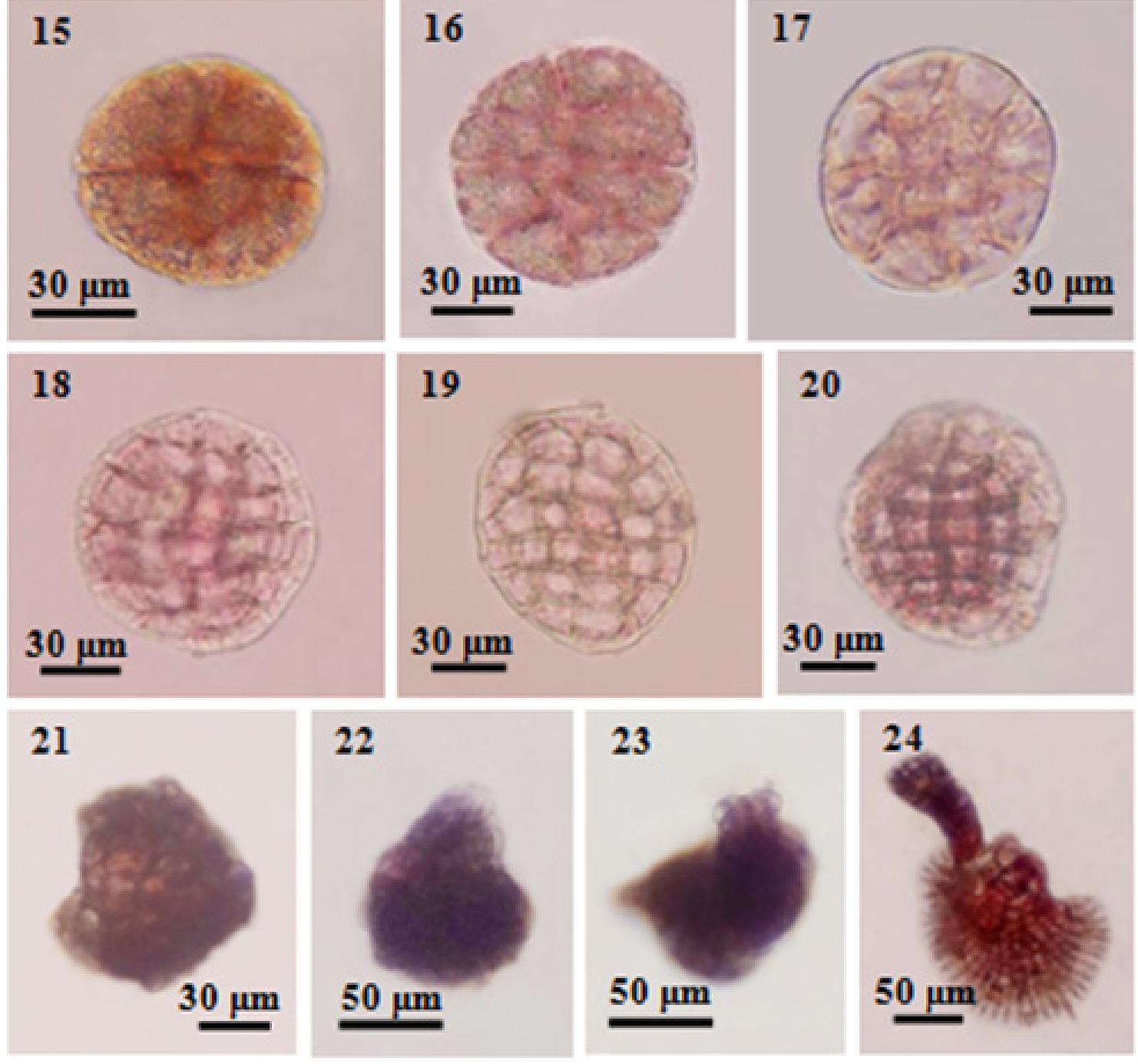

Figures I 2-24 Tetraspores germination of Amphiroa fragilissima: (I2) Liberated tetraspores from the conceptacles; (I3) Released tetraspore; (I4) The first cell division of tetraspore showing approximately equal 2 cells (I-2 hrs after attachment); (I5) The second cell division of tetraspore germling showing 4 cells; (I6) Tetrasporeling consisting of 8 cells ( 9 hrs after attachment); ( 17$)$ Tetrasporeling consisting of I 2 cells; ( 18 ) Tetrasporeling consisting of I6 cells; ( 19 ) Tetrasporeling consisting of 24 cells (I9-20 hrs after attachment); (20-2I) Developmental satges of hemispherical sporelings (I-2 days old); (22) Upright germling with initials of geniculum and intergeniculum ( 3 days old); (23-24) The development of erect plants ( 7 days old). 


\section{Discussion}

The plants of $A$. fragilissima form a dense clump at the tide pools of intertidal and subtidal zones and may be recognized by the smaller cylindrical branches, angles variable but mostly narrowed, and prominent swollen joints. Lamouroux ${ }^{20}$ established the genus Amphiroa in 1812 and firstly reported A. fragilissima in $1816 .{ }^{21}$ Kützing's ${ }^{22}$ illustration of $A$. fragilissima showed rounded cortical cells in surface view and thin cortex in longitudinal section of this species. However, rounded to hexagonal cortical cells in surface view and thick cortex (2-6 layers) are observed in A. fragilissima from Myanmar. Likewise, Weber-van Bosse ${ }^{23}$ described the distinguished characters of A. fragilissimaa such as 1) cylindrical intergenicula with swollen padlike genicula at top and base or not swollen a young state, 2 ) rows of cells in central strand almost horizontal not curved, and 3) conceptacles very prominent. Yendo ${ }^{24}$ discussed that genicula of this species were more swollen at their distal end.

Dawson ${ }^{25}$ discussed the variabilities of diameter, nodal swelling, and the angle of branching of A. fragilissima. Womersley and Baily ${ }^{26}$ supposed that an ecological form of $A$. fragilissima was similar with anastomosing erect and tightly packed form of A. anastomosan. However, the former had thickened nodes in older parts but that was not the case in the latter. The characters of the Sri Lankan species are hemispherical tufts forming cylindrical and divaricately dichotomous branching having small and conspicuous conceptacles. ${ }^{27}$ RosasAlquicira et al., ${ }^{28}$ reported the current placement of $A$. fragilissima in taxonomic biodiversity of geniculate corallines from the Macaronesian regions.

Rosas-Alquicira et al., ${ }^{29}$ described the segregating characters of $A$. fragilissima from Azores as 1) axes mainly terete, 2) branching mostly trichotomous, commonly in the genicula, rarely in the intergenicula, 3 ) apical intergenicula terete in transverse section and not reducing in diameter towards the apex, 4) five tiers of cells in the core region of the genicula, and one to four tiers of long cells vs. one tier of short cells in the core region of the intergenicula. The specimens of Myanmar agree with those of Azores species in having terete axes, branching di-trichotomous, terete intergenicula apex and the presence of 5 tiers of medullary cells in genicula. However, A. fragilissima of Myanmar possessed 7-8 tiers of long medullary cells followed by 1 tier of short medullary cells in intergenicula, whereas those form Azores showed 1-4 tiers of long cells followed by 1 tier of short cells in the core region of the intergenicula.

Vijaya \& Untawale ${ }^{30}$ also described the arrangement of long and short medullary cells in intergenicula of $A$. fragilissima. According to their description, there are four to six rows of long cells followed by a row of short cells but the number of long cells varies from two to five rows in this species. The meristematic cells at the apical region were covered by a single layer of cover cells which were $6-8 \mu \mathrm{m}$ in diameter. In addition, tetrasporangia arose from the entire floor of conceptacles and reproduction took place only by means of tetraspore in this species. In the present study, the apices of the intergenicula are also covered by a single layer of cover cells and only tetrasporophytic plants were observed in A. fragilissima.

According to data compared with characters of this species from Myanmar and different countries, the lengths of plants are up to 4 $\mathrm{cm}$ in specimens from Myanmar (the present study), America ${ }^{31}$ and $\mathrm{Cuba}^{32}$ and up to $6 \mathrm{~cm}$ high in Philippines ${ }^{33}$ and Santiago Is. ${ }^{34}$ The di- to trichotomous branching can be observed in all of the materials under comparison. The characteristics found in plants from Myanmar, those are, the nodal adventitious branches bearing from intergenicula and abundance of conceptacles at intergenicula agreed well with the illustrations of this species given by Dawson..$^{25}$ The intergenicula of Sri Lankan ${ }^{27}$ species showed up to $1 \mathrm{~cm}$ while those were less than $1 \mathrm{~mm}$ in diameter in all other plants described and the smallest intergenicula $(0.2-0.3 \mathrm{~mm}$ in diam.) are found at Myanmar's materials. The medullary cells of intergenicula arranged by up to 8 tires of long cells, alternating with 1 tier of short cells may be observed in the species from Myanmar, Thailand, ${ }^{35}$ Siboga Is. ${ }^{23}$ Philippines, ${ }^{33}$ America, ${ }^{31}$ and $\mathrm{Cuba}^{32}$ except those from Santiago Is., which have 5-6 rows of elongate cells, alternating with 1 row of short cells.

To investigate the spore germination of articulated coralline algae, the mature tetrasporophytic plants of $A$. fragilissima, were cultured under the laboratory condition. The plants A. fragilissima were abundantly found along the intertidal zone of the Chaungtha coastal areas almost all year round. These plants were mainly collected from Chaungtha for cultural studies in where the range of salinity was 3235 . Therefore, liberated tetraspores were cultured in sterile seawater which was salinity 32 and 35, enriched with PES culture medium in laboratory. In these salinity, the copious quantities of tetraspores were released from conceptacles of plants, and successive divisions of tetraspores took place and well developed well in culture. The cultured Petri dishes were placed near the full window light (not direct sunlight) in laboratory at room temperature. Under observation, the rate of release of tetraspores from conceptacles of the three species revealed that $A$. fragilissima shed an average of 75 spores per conceptacle (range 50-100) in 5h. The range of spores' diameters of the A. fragilissima was $40-80 \mu \mathrm{m}$ during a few hours after liberation.

For successful attachment, all these species required to immerse continuously because they could not survive about a few minutes period of desiccation. Under a higher magnification of light microscope, the attached spores were found to be covered by a substance on the surface. These substances were spreading into the rims of spores forming more than one to two concentric band of refractive material. Liberated spores of A. fragilissima settled to the cover slips and a first division formed within 1-2h of attachment. A second division occurred during 5-6h. During 9-20h after attachment, 8-24-celled stages were observed after successive cell divisions. The hemispherical forms of sporelings were observed after 1-2d. The initial of upright axis occurred during $3 \mathrm{~d}$ in culture. Some spores did not give rise to young erect plants but continued to grow fringe-like and fan-shaped expanded crusts until these developed to $100-150 \mu \mathrm{m}$ in diameter.

In the present study, petri dishes containing spores were placed near the window under natural light intensity. So, light intensity received by the spores was measured in day time. According to measurements the range of light intensity was $10-20 \mathrm{ft}-\mathrm{c}$. The normal growth of spore germination of three species was observed at the range of 16$20 \mathrm{ft}-\mathrm{c}$ and some of spores grew continuously to be extensive crusts which did not give rise to the upright young plants under the low light intensity, 10-11ft-c.

There are three main patterns of spore germination observed in the laboratory culture of Amphiroa: I) upright sporelings growth arising from the basal crust; II) fan-shaped growth with a fringe-like peripheral thallus; and III) fan-shaped growth (Figure 25). It was assumed that 
development of sporelings depended on the light condition: the upright plants may be observed under the sufficient light conditions where as fringe-like and fan-shaped thalli may be formed under the low light and unfavourable conditions. In fringe-like and fan-shaped thalli, the distinguished characters of coralline algae such as primary and secondary pit- connections and presence and absence of lateral fusions between the cells, rectangular shape of cells, and megacells (heterocyst, trichocytes) were observed respectively.

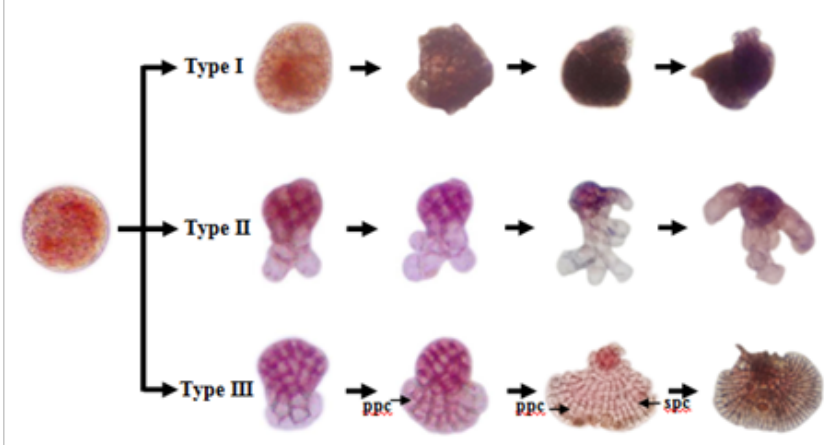

Figure $\mathbf{2 5}$ The three patterns of spore germination of Amphiroa:Type I- upright sporelings growth arising from the basal crust; Type II- fan-shaped growth with a fringe-like peripheral thallus; Type III- fan-shaped growth. Abbreviations: Ppc, primary pit connection; spc, secondary pit connection.

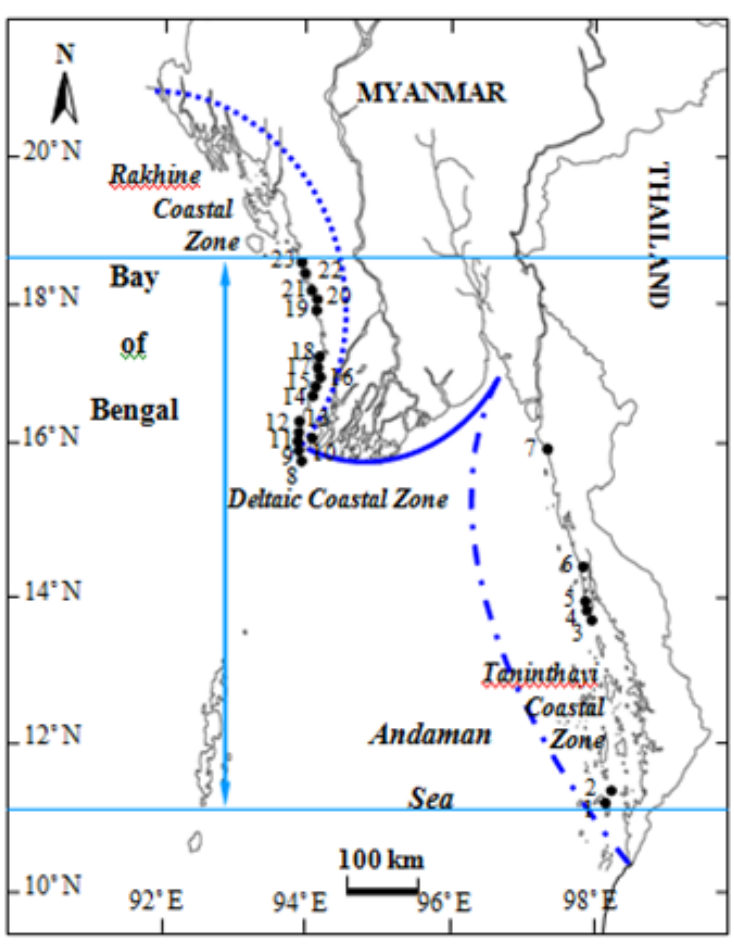

Figure 26 Distribution of Amphiroa fragilissima along the 3 Coastal Zones of Myanmar. I. Lampi I., 2. High I., 3. Wa Maw, 4. Nyaw Byin, 5. Kampani, 6. Mway Taung, 7. Setse, 8. Leik I., 9. Mawtin Point, I0. Hi Gyi, II. Kyar Kan, I2. Zee Gyaing, 13. Pashyu Gyaing, 14. Sinma, I5. Ngwe Saung, I6. Phoe Kalar I., 17. Makyee, 18. Wetthey Gyaing, 19. Maw Shwe Gyaing, 20. Sin Phyu Gyaing, 21. Leik Tet Gyaing, 22. Maungshwelay, 23. Gyeik Taw. Symbols: Distribution range of A. fragilissima; _ . _ . - Taninthayi Coastal Zone; Deltaic Coastal Zone;

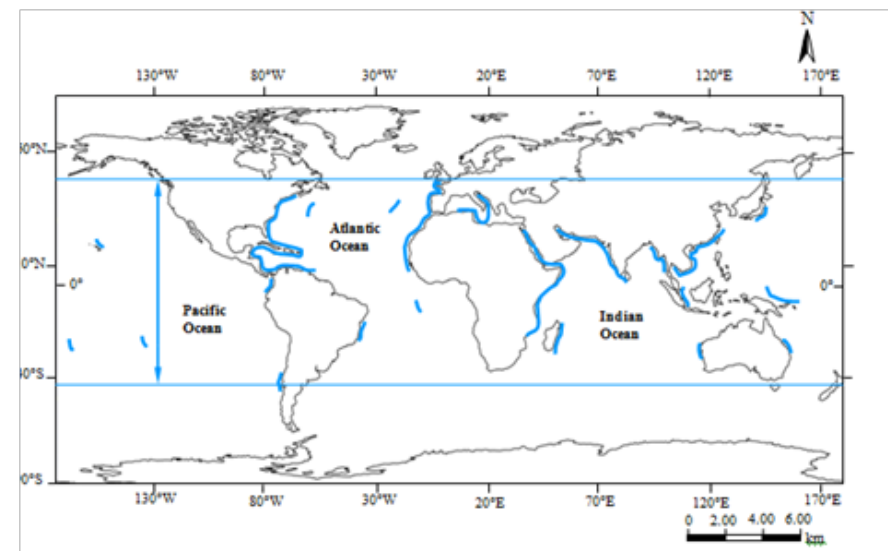

Figure 27 Phytogeographical distribution of the Amphiroa fragilissima. Symbol: Potential distribution range and southernmost and northernmost recorded limits of A. fragilissima.

Yamada (1959) suggested that coralline algae may be divided into three groups such as articulated corallines 1) Amphiroa ephedraea, 2) Corallina pilulifera and crustose coralline 3) Fosliella types according to the mode of spore germination (as cited in Johansen ${ }^{1}$ ). Notoya $^{36}$ described the schematic diagram of Amphiroa-type of spore germination in the three species of crustose coralline algae such as Tenarea corallinae, T. dispar and T. tumidula. According to his descriptions, first to fifth cell divisions gave rise to 2-24-celled stages. Similarly, 2-24-celled stages of Amphiroa-type were observed in the germination of $A$. fragilissima in the present study.

In Myanmar, Martens ${ }^{6}$ firstly reported A. fragilissima from South Andaman Sea. Soe-Htun ${ }^{9}$ reported A. fragilissima from Rakhine and Tanintharyi coastal zones. In addition, Soe-Htun et al., ${ }^{10}$ described $A$. fragilissima from the Gwa coastal areas, Rakhine State. Soe-Htun et al., ${ }^{11}$ reported this species growing along Rakhine and Tanintharyi coastal zones. In present study, A. fragilissima occurred along the three coastal zones of Myanmar from Lampi I (Lat. $10^{\circ} 58^{\prime} \mathrm{N}$, Long. $98^{\circ} 08^{\prime} \mathrm{E}$ ) in the south to Gyeik Taw (Lat. $18^{\circ} 21^{\prime} \mathrm{N}$, Long. $94^{\circ} 20^{\prime} \mathrm{E}$ ) in the north. Surprisingly, it was only one articulated coralline species which can be found in Setse, deltaic coastal zone where the salinity was 5 in the raining season and 31 in the summer. Moreover, $A$. fragilissima distributed from Lampi I. (Lat. $10^{\circ} 58^{\prime} \mathrm{N}$, Long. $98^{\circ} 08^{\prime}$ E) to Mway Taung (Lat. $14^{\circ} 27^{\prime} \mathrm{N}$, Long. $98^{\circ} 00^{\prime} \mathrm{E}$ ) along Tanintharyi coastal zones and Leik I. (Lat. $15^{\circ} 51^{\prime} \mathrm{N}$, Long. $94^{\circ} 17^{\prime} \mathrm{E}$ ) to Gyeik Taw (Lat. $18^{\circ} 21^{\prime} \mathrm{N}$, Long. $94^{\circ} 20^{\prime} \mathrm{E}$ ) along Rakhine coastal zone where the salinity was generally 28 in the raining season and 35 in the summer. So, it was assumed that $A$. fragilissima was likely euryhaline species tolerant a range of salinity from 5 to 35 . It revealed the wide phytogeographic distribution range from France as the northernmost recorded limit to Chile as the southernmost recorded limit.

\section{Conclusion}

A study on the taxonomy, spore germination and phytogeographical distribution of the articulated coralline alga $A$. fragilissima was conducted. According to detailed taxonomic studies, main characteristics of this species are observed as follows: (1) thalli are erect with cylindrical branches; (2) genicula are swollen and prominent, consisting of 3-5 tiers of medullary cells; (3) intergenicula are terete or subterete composed of 7-8 tires of long medullary cells, alternating with 1 tier of short cells; and (4) primary and secondary pit-connections are present in medullary filaments of the 
intergenicula. Consequently, cultural studies on the spore germination of A. fragilissima were carried out in order to know the development patterns under the laboratory conditions. Cell divisions of tetraspores from 2 to 24-celled stages were observed during $20 \mathrm{~h}$ after liberated from conceptacles. The cell divisions of Amphiroa-type were observed in spore germination of this species. Consequently, the initial of upright axis formed at the center of dome-like sporelings on the 3rd day and a recognisible plant with a distinct upright axis and a fully developed basal crust was formed during $7 \mathrm{~d}$ in A. fragilissima. A. fragilissima occurs along the 3 coastal areas distribution. With regard to geographical distribution, A. fragilissima widely distributes throughout tropical and subtropical regions of all of the oceans.

The articulated coralline algae provide microhabitat for many epiphytes and invertebrates. It is also provide as nursery grounds for fish larvae. Now, the coralline algae are vulnerable to the changes in the oceans as a result of increasing atmospheric $\mathrm{CO}_{2}$. The fundamental changes in seawater chemistry such as decreasing $\mathrm{pH}$, increasing acidity, and disruption of the local and global carbon cycle have occurred because of increasing atmospheric $\mathrm{CO}_{2}$ and increasing temperature. These changes may cause a negative effect on coralline algae and consequent impacts on the living resources. Therefore, the researches emphasized on the role of coralline algae are still needed to carry out.

\section{Acknowledgements}

I am indebted to Dr. Aung Myat Kyaw Sein, Rector of Mawlamyine University, Dr. Mie Mie Sein and Dr. San San Aye, Pro-Rectors of Mawlamyine University for their permission to carry out this research work. I would like to express my gratitude to Dr. San Tha Tun, Professor and Head of Department of Marine Science, Mawlamyine University, for his valuable guidance and for providing the departmental facilities. Thanks are due to U Soe-Htun, Professor and Head (Retired), Department of Marine Science, and Head of Department of Marine Science, Mawlamyine University and Chairman of Marine Science Association, Myanmar (MSAM), for his guidance during this research work. Thanks are also due to all my respected teachers and colleagues for their encouragement. Finally, my infinite thanks are attributive to my beloved parents for their kind support made to reach the goal of this work.

\section{Conflict of interest}

The author declares that there is no conflict of interest.

\section{References}

1. Johansen HW. Morphology and systematics of coralline algae with special reference to Calliathron. University of California Publications in Botany. 1994;49:78.

2. Silva HW, Johansen HW. A reappraisal of the order Corallinales (Rhodophyceae). Br. Phycol. J. 1986;21(3):245-254.

3. Aguirre J, Perfectti F, Braga JC. Integrating phylogeny, molecular clocks, and the fossil record in the evolution of coralline algae (Corallinales and Sporolithales, Rhodophyta). Paleobiology. 2010;36(4):519-533.

4. Guiry MD, Guiry GM. Algae Base. World-wide electronic publication, National University of Ireland, Galway. 2013.

5. Norris JN, Johansen HW. Articulated coralline algae of the Gulf of California, Mexico, I: Amphiroa Lamouroux. Smithsonian Institution Press. Smithsonian Contributions to the Marine Sciences. 1981;(9):29.
6. Martens Gv. List of algae collected by Mr. S. Kutz in Burma and adjacent islands. Stallyardt. 1871. 461-469 p.

7. Kyi Win. A classified list of the seaweeds of Burma. Proceedings of the Burma Research Congress.1972. p.25-29.

8. Kyaw Soe, Kyi Win. Seaweeds for utilization. University Translation and Publication Department. Publication. 1977;2(168):502.

9. Soe Htun U. The Seaweed Resources of Myanmar. In: Critchley AT, Ohno M, editors. Seaweed resources of the world. Kanakawa International Fisheries Training Center, Japan International Cooperation Agency (JICA). 1998. p. 99-105.

10. Soe Htun, Mya Kyawt Wai, Thida Nyunt, et al. Notes on some marine benthic red algae of Gwa Coastal Areas I. Rhodophyta (Goniotrichales, Stylonematales, Erythropeltidales, Bangiales, Acrochaetiales, Nemaliales, Corallinales, Gelidiales and Halymeniales. Jour Myan Acad Arts \& Sc. 2009;7(5):115-142.

11. Soe Htun, Mya Kyawt Wai, Thida Nyunt, et al. Checklist, distribution and potential utilization of marine algae of Myanmar II. Rhodophyta (Red algae). Jour Myan Acad Arts \& Sc. 2009;7(5):279-305.

12. Mya Kyawt Wai. Systematics of the Articulated Corallinaceae (Corallinales, Rhodophyta) of Myanmar. Unpublished $\mathrm{PhD}$ Thesis. Department of Marine science, University of Mawlamyine. 2013. 246 p.

13. Johansen HW. Reproduction of the articulated coralline Amphiroa ephedraea. J. Phycol. 1968;4:319-328.

14. Womersley HBS, Johansen HW. Subfamily Amphiroideae Johansen. In: Womersley HBS, editors. The marine benthic flora of Southern Australia. Rhodophyta. Part IIIB. Commonwealth of Australia, Union Offset, Canberra. 1996a. p. 283-288.

15. Womersley HBS, Johansen HW. Subfamily Corallinoideae (Areschoug) Foslie. In: Womersley HBS editors. The marine benthic flora of Southern Australia. Rhodophyta. Part IIIB. Commonwealth of Australia, Union Offset, Canberra. 1996b. p. 288-317.

16. Bittner L, Payri CE, Maneveldt GW, et al. Evolutionary history of the Corallinales (Corallinophycidae, Rhodophyta) inferred from nuclear, plastidial and mitochondrial genomes. Molecular Phylogenetics and Evolution. 2011;61:697-713.

17. Provasoli L. Media and prospects for the cultivation of marine algae. In: Waternable A, Hattoria A, editors. Cultures and Collection of Algae, Proc. U.S. Japan Conf. Hakone, Jap Soc Pl Physiol. 1968. p. 63-75.

18. Silva PC, Basson PW, Moe RL. Catalogue of the benthic marine algae of the Indian Ocean. University of California Publications in Botany. 1996;79:1259.

19. Guiry MD. AlgaeBase Beta Version. World-wide electronic publication, National University of Ireland, Galway.

20. Lamouroux, J.V.F. 1812. Sur la classification des Polypiers coralligenes non entierement pierreux. Nouv Bull Sci Soc Philom Paris. 2009;3:181188.

21. Lamouroux JVF. Histoire des Polypiers Coralligenes Flexibles. 1816. $558 \mathrm{p}$.

22. Kutzing FT. Tabulae phycologicae. Volume VIII, ii +48 pages, 100 plates. Nordhausen. 1858 .

23. Weber-van Bosse A. Corallineae verae of the Malay Archipelago, In Weber-van Bosse \& Foslie, M., The corallinaceae of the Siboga Expedition. Siboga-Expeditae, Monogr. 1904;111:78-110.

24. Yendo K. A revised list of Corallinae. J. Coll Sci. Imp. Univ. Tokyo. 1905;20:1-46. 
25. Dawson EY. Marine algae in the vicinity of the Institut Oceanographique de Nhatrang, Vietnam. Pacif. Sci. 1954;8(4):373-481.

26. Womersley HBS, Bailey A. Marine algae of the Solomon Islands. Philosophical Transactions of the Royal Society of London. 1970;259:257-352.

27. Coppejans E, Leliaert F, Dargent O, et al. Sri Lankan seaweeds. Methodologies and field guide to the dominant species. 2009;6:265p.

28. Rosas-Alquicira EF, Riosmena-Rodríguez R, Afonso-Carrillo J, et al Taxonomic biodiversity of geniculate coralline red algae (Corallinales, Rhodophyta) from the Macaronesian region: summary and analysis. Helgol Mar Res. 2011;65(2):133-153.

29. Rosas-Alquicira EF, Riosmena-Rodríguez R, Neto AL. Segregating characters used within Amphiroa (Corallinales, Rhodophyta) and taxonomic reevaluation of the genus in the Azores. J Appl Phycol. 2011;23(3):475-488.

30. Vijaya A, Untawale AG. Bioecology of an articulated coralline alga Amphiroa fragilissima from Anjuna, Goa, Central Western Coast of India. National Institue of Oceanography, Goa. 1991;1-8.
31. Taylor WR. Marine algae of the eastern tropical and subtropical coast of the Americas. The University of Michigan Press. Uni. of Michigan studies Scientific Senes. 1967;21:870.

32. Kusel H. Contribution to the knowledge of the seaweeds of Cuba. Botanica Marina. 1972;15:186-198.

33. Cordero Jr PA. Studies on Philippine marine red algae. Special. Publ. Seto Marine Biol. Lab., Series IV. Contr. Seto Mar Biol Lab. 1977;(632):258.

34. Saraya A, Trono GC. The marine benthic algae of Santiago Island and adjacent areas in Bolinao, Pangasinan, II. Rhodophyta. Natural and Applied Science Bulletin. University of the Philippines. 1982;43(1):2583.

35. Lewmanomont K, Ogawa H. Common seaweeds and seagrasses of Thailand. Fac. Fish, Kasetsart Univ. 1995. 163 p.

36. Notoya M. Spore germination in crustose coralline Tenarea corallinae, T. dispar, T. tumidula. The Bulletin of Japanese Society of Phycology.1974;22(2):47-51. 